\title{
Optimizing Initiation and Maintenance of Vitis Embryogenic Cultures
}

\author{
Sadanand A. Dhekney and Zhijian T. Li \\ Mid-Florida Research and Education Center, University of Florida/IFAS, \\ 2725 Binion Road, Apopka, FL 32703-8504
}

Michael E. Compton

School of Agriculture, University of Wisconsin-Platteville, 1 University Plaza, Platteville, WI 53818-3099

Dennis J. Gray ${ }^{1}$
University of Florida, Mid-Florida Research and Education Center, 2725
Binion Road, Apopka, FL 32702-8504

Additional index words. grapevine, somatic embryogenesis, culture media, growth regulators

Abstract. Stamens and pistils from mature grapevines and leaves from in vitro micropropagation cultures were used to optimize parameters influencing somatic embryogenesis in Vitis. Embryogenic competence was dependent on species/variety, explant type and developmental stage, medium composition, and growth regulator concentration. Of varieties evaluated, a greater number produced embryogenic cultures from stamens and pistils (26) compared with leaves (six). Among the different stamen and pistil stages, Stage II and III explants produced the maximum embryogenic response regardless of genotype and medium composition. Of seven culture media tested, the highest embryogenic response was recorded from varieties cultured on MSI (18) and PIV (16) media. Experiments annually repeated over 3 to 10 years demonstrated reproducible results. Highly reliable protocols for somatic embryogenesis were obtained for 29 Vitis species and varieties, including 18 Vitis vinifera varieties, Vitis riparia, Vitis rupestris, Vitis champinii, and eight Vitis hybrids. Embryogenic cultures were maintained on X6 medium for a period of 6 months to 2 years depending on the variety and used in studies involving genetic transformation and transgenic plant regeneration.

Genetic engineering of Vitis has emerged as an alternative to conventional breeding for the introduction of desirable traits into elite varieties. The routine use of embryogenic cultures for grapevine transformation (Gray et al., 2005) necessitates optimization of protocols for culture initiation and maintenance. Although somatic embryogenesis from Vitis was reported previously (Carmi et al., 2005; Gray and Mortensen, 1987; Kikkert et al., 2005; Perrin et al., 2001), few varieties displayed embryogenic competence and wide variations among responsive varieties were observed. To improve embryogenic competence and produce cultures that result in genetically stable regenerants, factors that influence somatic embryogenesis, including explant type and developmental stage, macro- and microelement composition of the culture medium and growth regulator concentration warrant exam-

Received for publication 10 Apr. 2009. Accepted for publication 27 May 2009.

This research was supported by the Florida Agricultural Experiment Station and the Florida Department of Agriculture and Consumer Services' Viticulture Trust Fund.

We thank the Foundation Plant Services, University of California, Davis, CA, for providing dormant cuttings used in this study.

${ }^{1}$ To whom reprint requests should be addressed; e-maildjg@ufl.edu. embryogenic competence. A number of medium formulations are currently used for culture initiation for grapevine (Kikkert et al., 2005; Perrin et al., 2004). Identification
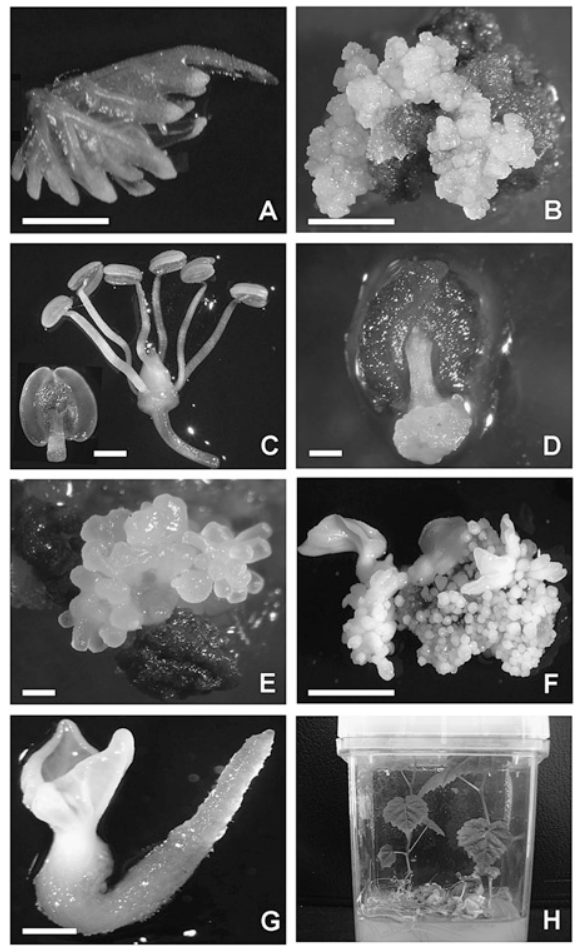

Fig. 1. Embryogenic culture system in Vitis. Unopened leaves (A) cultured on initiation medium produce sectors of embryogenic and nonembryogenic callus (B). (C) Stamen and pistil explants from unopened grapevine inflorescence. (Inset) A single stamen in an inverted position to show the filament connected to the anther. Callus production from filament tip (D) or connective tissue (E) of stamens. (F) Somatic embryo development and proliferation after transfer of embryogenic callus to X6 medium. (G) Germination of cotyledonary stage somatic embryo and plant regeneration (H). Scale bars: $\mathbf{A}=1 \mathrm{~mm} ; \mathbf{B}, \mathbf{F}=5 \mathrm{~mm} ; \mathbf{C}, \mathbf{G}=$ $0.5 \mathrm{~mm} ; \mathbf{D}, \mathbf{E}=0.1 \mathrm{~mm}$.
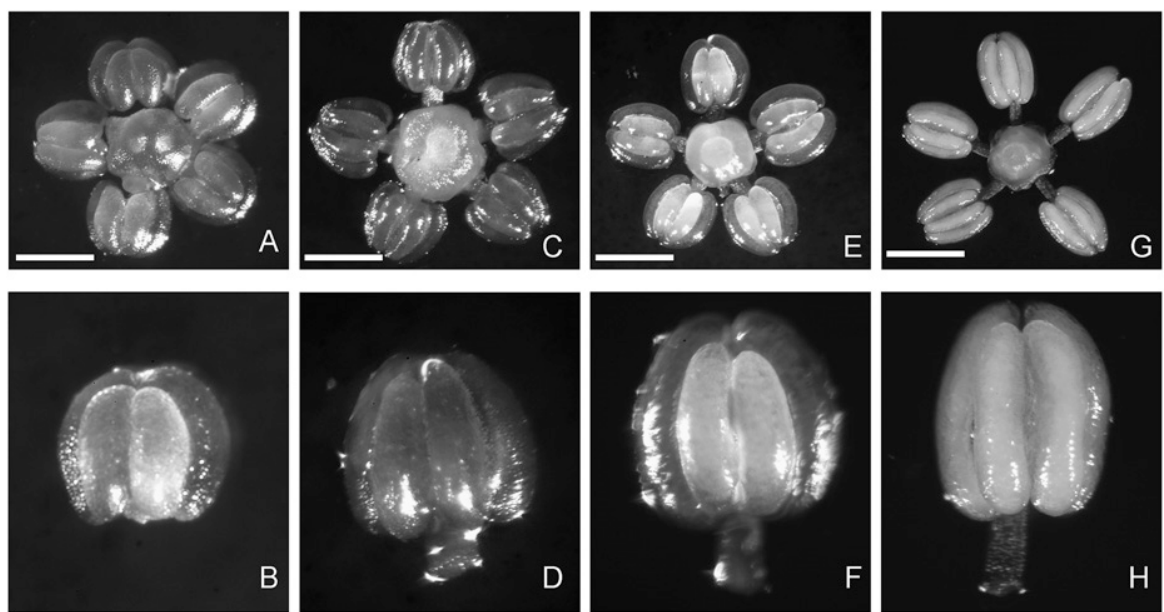

Fig. 2. Stamen and pistil explant stages in Vitis. Four stages, Stage I (A-B), Stage II (C-D), Stage III $(\mathbf{E}-\mathbf{F})$, and Stage IV $(\mathbf{G}-\mathbf{H})$, were identified based on appearance of explants and development of microspores. Scale bars: $\mathbf{A}=0.1 \mathrm{~mm}, \mathbf{C}=0.8 \mathrm{~mm}, \mathbf{E}, \mathbf{G}=1.0 \mathrm{~mm}$. 
of one to a few useful culture media would facilitate initiation of embryogenic cultures for Vitis species and varieties.

We studied factors including explant type and developmental stage, medium composition, and growth regulator concentrations repeatedly over a period of 3 to 10 years to optimize production of embryogenic cultures. Cultures were obtained in 29 Vitis species and varieties.

\section{Materials and Methods}

\section{Influence of genotype and explant type}

Embryogenic competence of in vitroderived leaves, pistils, and stamens from 29 grape varieties, including 18 Vitis vinifera varieties, Vitis champinii Planch., Vitis riparia Michx., Vitis rupestris Scheele, and eight Vitis interspecific hybrids, was evaluated over a period of 10 years depending on the availability of explant material. Leaf explants of $V$. vinifera 'Autumn Seedless', 'Chardonnay', 'Cabernet Franc', 'Cabernet Sauvignon', 'Merlot', 'Pinot Noir', 'Semillon', 'Superior Seedless', 'Thompson Seedless', and 'White Riesling'; V. rupestris 'St. George'; and Vitis hybrids 'Blanc du Bois', 'Freedom', 'Seyval Blanc', and 'Tampa' were obtained from in vitro shoot cultures (Gray and Benton, 1991). Unopened leaves, 1.5 to $5.0 \mathrm{~mm}$ long (Fig. 1A), were placed abaxial side down on NB2 medium (Table 1). Five leaves were placed in each petri dish and incubated in darkness at $26{ }^{\circ} \mathrm{C}$ for 5 to 7 weeks. Resulting callus cultures (Fig. 1B) were transferred to cool white fluorescent light $\left(65 \mu \mathrm{m} \cdot \mathrm{m}^{-2} \cdot \mathrm{s}^{-1}\right.$ and 16h photoperiod) at $26^{\circ} \mathrm{C}$ for 5 weeks. Culture development was screened weekly and embryogenic callus was transferred to growth regulator-free X6 medium (Dhekney et al., 2008) for development of proembryonic masses (PEM) and somatic embryos (SE). Further PEM and SE proliferation occurred on X6 medium.

Inflorescences of 26 Vitis varieties (Table 2) were obtained either from the Mid-Florida Research and Education Center vineyard or from dormant vine cuttings obtained from the Foundation Plant Services, University of California, Davis, CA. Inflorescence development from dormant cuttings, $30 \mathrm{~cm}$ in length, was induced after surface sterilization in $25 \% \mathrm{NaClO}$ solution with constant agitation for 5 min followed by two washes with sterile distilled water. Cuttings were forced to flower by placing them basal end down in 500-mL Erlenmeyer flasks containing $250 \mathrm{~mL}$ sterile distilled water to a growth room with cool-white fluorescent lights (65 $\mu \mathrm{mole} \cdot \mathrm{m}^{-2} \cdot \mathrm{s}^{-1}$ and a 16 -h photoperiod), at $26{ }^{\circ} \mathrm{C}$ for 3 weeks. Water was replaced and the basal $1 \mathrm{~cm}$ of each cutting was trimmed at weekly intervals. Inflorescences were excised and samples of individual flowers were dissected and observed with a stereomicroscope to determine the developmental stage of stamens and pistils (Fig. 1C). Inflorescences at varying developmental stages were surfacesterilized by immersion in $70 \%$ ethanol for $30 \mathrm{~s}$ followed by washing them in distilled water for
Table 1. Composition of media tested for embryogenic culture initiation in Vitis.

\begin{tabular}{lccccccc}
\hline Medium $^{\mathrm{z}}$ & $\begin{array}{c}\text { Macro- and } \\
\text { microelements }\end{array}$ & $\begin{array}{c}\text { BAP } \\
(\mu \mathrm{M})\end{array}$ & $\begin{array}{c}2,4-\mathrm{D} \\
(\mu \mathrm{M})\end{array}$ & $\begin{array}{c}\text { NOA } \\
(\mu \mathrm{M})\end{array}$ & $\begin{array}{c}\text { Sucrose } \\
(\%)\end{array}$ & $\begin{array}{c}\text { Gelling agent } \\
\text { and concn }\left(\mathrm{g} \cdot \mathrm{L}^{-1}\right)\end{array}$ & $\mathrm{pH}$ \\
\hline MSI & MS & 4.5 & 5.0 & - & 2.0 & Agar $(7.0)$ & 6.0 \\
MSII & MS & 5.0 & 2.5 & 2.5 & 2.0 & Agar (7.0) & 6.0 \\
X1 & MS & 5.0 & 2.5 & 2.5 & 2.0 & Agar (7.0) & 5.8 \\
X2 $^{\mathrm{y}}$ & MS & 5.0 & 15.0 & 2.5 & 2.0 & Agar (7.0) & 5.8 \\
PIV & Nitsch & 8.9 & 4.5 & - & 6.0 & Phytagel (3.0) & 5.7 \\
NI & Nitsch & 5.0 & 2.5 & 2.5 & 2.0 & Agar (7.0) & 5.8 \\
NII & Nitsch & 5.0 & 15.0 & 2.5 & 2.0 & Agar (7.0) & 5.8 \\
NB2 & Nitsch & 1.0 & 5.0 & - & 2.0 & Agar (7.0) & 6.0 \\
\hline
\end{tabular}

${ }^{\mathrm{z}} \mathrm{All}$ media were supplemented with $0.1 \mathrm{~g} \cdot \mathrm{L}^{-1}$ myo-inositol and MS vitamins.

${ }^{\mathrm{y}} \mathrm{X}$ medium $=$ modified MS medium lacking glycine and MS nitrate was replaced with X nitrate comprising of $3.033 \mathrm{~g} \cdot \mathrm{L}^{-1} \mathrm{KNO}_{3}$ and $0.364 \mathrm{~g} \cdot \mathrm{L}^{-1} \mathrm{NH}_{4} \mathrm{Cl}$ (as the sole nitrogen source).

xPIV medium (Franks et al., 1998) was supplemented with B5 vitamins instead of MS vitamins pH was adjusted with $\mathrm{KOH}$ before autoclaving.

Table 2. Embryogenic response of Vitis stamens and pistil explants (Stage I to IV).

\begin{tabular}{|c|c|c|c|c|c|}
\hline Variety & Stage & $\begin{array}{c}\text { No. of } \\
\text { stamens } \\
\text { cultured }\end{array}$ & $\begin{array}{c}\text { Percent } \\
\text { embryogenic } \\
\text { stamens } V \text {. vinifera }\end{array}$ & $\begin{array}{l}\text { No. of } \\
\text { pistils } \\
\text { cultured }\end{array}$ & $\begin{array}{c}\text { Percent } \\
\text { embryogenic } \\
\text { pistils }\end{array}$ \\
\hline \multirow[t]{4}{*}{$\overline{\text { Barbera }(3)^{z}}$} & I & 35 & 0 & 5 & 0 \\
\hline & II & 280 & 0 & 40 & 2.5 \\
\hline & III & 210 & 0 & 30 & 0 \\
\hline & IV & 1,960 & 0.05 & 280 & 1.1 \\
\hline \multirow[t]{4}{*}{ Cabernet Franc (7) } & I & 245 & 2.4 & 35 & 2.0 \\
\hline & II & 1,855 & 2.5 & 265 & 5.3 \\
\hline & III & 8,330 & 1.4 & 1,190 & 5.3 \\
\hline & IV & 2,345 & 0.4 & 335 & 1.2 \\
\hline \multirow[t]{4}{*}{ Cabernet Sauvignon (10) } & I & 3,185 & 0.1 & 455 & 0.2 \\
\hline & II & 23,730 & 0.06 & 3,390 & 0.5 \\
\hline & III & 15,505 & 0.4 & 2,215 & 1.7 \\
\hline & IV & 5,425 & 0.1 & 775 & 1.3 \\
\hline \multirow[t]{4}{*}{ Chardonnay (8) } & I & 595 & 1.8 & 85 & 3.5 \\
\hline & II & 6,545 & 1.5 & 935 & 3.3 \\
\hline & III & 3,885 & 1.4 & 555 & 3.4 \\
\hline & IV & 1,470 & 0.7 & 210 & 4.8 \\
\hline \multirow[t]{4}{*}{ Dolcetto (3) } & I & 1,050 & 0.1 & 150 & 0 \\
\hline & II & 1,855 & 0 & 265 & 0 \\
\hline & III & 2,730 & 0 & 390 & 0 \\
\hline & IV & 2,100 & 0 & 300 & 0 \\
\hline \multirow[t]{4}{*}{ Emerald Seedless (3) } & I & 945 & 1.3 & 135 & 0 \\
\hline & II & 805 & 3.5 & 115 & 0.9 \\
\hline & III & 225 & 7.3 & 175 & 0 \\
\hline & IV & 595 & 2.9 & 85 & 1.2 \\
\hline \multirow[t]{4}{*}{ Merlot (9) } & I & 980 & 5.4 & 140 & 0.0 \\
\hline & II & 5,775 & 9.9 & 825 & 9.3 \\
\hline & III & 5,495 & 11.6 & 785 & 13.8 \\
\hline & IV & 2,170 & 3.0 & 310 & 3.9 \\
\hline \multirow[t]{4}{*}{ Pinotage (3) } & I & 525 & 0 & 75 & 0 \\
\hline & II & 2,590 & 0 & 370 & 0.5 \\
\hline & III & 3,080 & 0.03 & 440 & 0.2 \\
\hline & IV & 315 & 0 & 45 & 0 \\
\hline \multirow[t]{4}{*}{ Pinot Gris (3) } & I & 175 & 1.7 & 25 & 4 \\
\hline & II & 1,785 & 0.7 & 255 & 0 \\
\hline & III & 1,470 & 0.07 & 210 & 0 \\
\hline & IV & 70 & 1.4 & 10 & 0 \\
\hline \multirow[t]{4}{*}{ Pinot Noir (3) } & I & 350 & 1.4 & 50 & 2 \\
\hline & II & 4,935 & 3.1 & 705 & 0.6 \\
\hline & III & 3,745 & 1.1 & 535 & 0.6 \\
\hline & IV & 3,850 & 1.2 & 550 & 2.0 \\
\hline \multirow[t]{4}{*}{ Sauvignon Blanc (5) } & I & 385 & 0.2 & 55 & 0 \\
\hline & II & 4,235 & 0.1 & 605 & 3.8 \\
\hline & III & 1,225 & 0.2 & 175 & 2.9 \\
\hline & IV & 245 & 1.2 & 35 & 17.1 \\
\hline \multirow[t]{4}{*}{ Shiraz (5) } & I & 140 & 0 & 20 & 0 \\
\hline & II & 2,485 & 0.6 & 355 & 0.3 \\
\hline & III & 1,715 & 0.5 & 245 & 0 \\
\hline & IV & 140 & 1.4 & 20 & 0 \\
\hline \multirow[t]{4}{*}{ Thompson Seedless (5) } & I & 1,260 & 9.5 & 180 & 0.6 \\
\hline & II & 1,050 & 10.5 & 150 & 4 \\
\hline & III & 1,120 & 9.9 & 160 & 3.1 \\
\hline & IV & 420 & 6.2 & 60 & 8.3 \\
\hline
\end{tabular}

(Continued on next page) 
Table 2. (Continued) Embryogenic response of Vitis stamens and pistil explants (Stage I to IV).

\begin{tabular}{|c|c|c|c|c|c|}
\hline Variety & Stage & $\begin{array}{l}\text { No. of } \\
\text { stamens } \\
\text { cultured }\end{array}$ & $\begin{array}{c}\text { Percent } \\
\text { embryogenic } \\
\text { stamens } V \text {. vinifera }\end{array}$ & $\begin{array}{l}\text { No. of } \\
\text { pistils } \\
\text { cultured }\end{array}$ & $\begin{array}{c}\text { Percent } \\
\text { embryogenic } \\
\text { pistils }\end{array}$ \\
\hline \multirow[t]{4}{*}{ White Riesling (10) } & I & 8,890 & 1.1 & 1,270 & 1.4 \\
\hline & II & 14,490 & 2.7 & 2,070 & 3.6 \\
\hline & III & 12,040 & 3.7 & 1,720 & 5.9 \\
\hline & IV & 3,605 & 2.1 & 515 & 4.3 \\
\hline \multirow[t]{4}{*}{ Zinfandel (6) } & I & 630 & 0 & 90 & 1.1 \\
\hline & II & 455 & 0 & 65 & 1.5 \\
\hline & III & 2,590 & 0.4 & 370 & 3.0 \\
\hline & IV & 2,310 & 0.04 & 330 & 0 \\
\hline \multirow{4}{*}{ V champinii (3) } & I & 350 & 0 & 50 & 0 \\
\hline & II & 490 & 0.2 & 95 & 0 \\
\hline & III & 700 & 1.85 & 100 & 0 \\
\hline & IV & 280 & 0 & 40 & 0 \\
\hline \multirow{4}{*}{ V. riparia Gloire (3) } & I & 245 & 0 & 35 & 0 \\
\hline & II & 1,330 & 0.2 & 190 & 1.1 \\
\hline & III & 3,570 & 0.5 & 510 & 2.4 \\
\hline & IV & 455 & 0.9 & 65 & 4.6 \\
\hline \multirow[t]{4}{*}{ V. rupestris St. George (3) } & I & 315 & 0 & 45 & 0 \\
\hline & II & 595 & 1.5 & 85 & 0 \\
\hline & III & 595 & 1.0 & 85 & 1.2 \\
\hline & IV & 385 & 0 & 55 & 0 \\
\hline \multicolumn{6}{|c|}{ Vitis hybrids } \\
\hline \multirow[t]{4}{*}{ Blanc du Bois (7) } & I & 2,065 & 0.4 & 295 & 0 \\
\hline & II & 3,710 & 0.3 & 530 & 0 \\
\hline & III & 6,860 & 0.2 & 980 & 0 \\
\hline & IV & 1,820 & 0.2 & 260 & 0 \\
\hline \multirow[t]{4}{*}{ Conquistador (5) } & I & 350 & 0 & 50 & 0 \\
\hline & II & 105 & 0 & 15 & 0 \\
\hline & III & 1,295 & 0.84 & 185 & 0.54 \\
\hline & IV & 805 & 0 & 115 & 1.7 \\
\hline \multirow[t]{4}{*}{ Freedom (5) } & I & 385 & 0 & 55 & 0 \\
\hline & II & 980 & 0 & 140 & 0 \\
\hline & III & 595 & 0 & 85 & 1.2 \\
\hline & IV & 735 & 0 & 105 & 5.7 \\
\hline \multirow[t]{4}{*}{ Harmony (3) } & I & 280 & 0 & 40 & 0 \\
\hline & II & 350 & 0.57 & 50 & 0 \\
\hline & III & 1,085 & 0.82 & 155 & 0 \\
\hline & IV & 315 & 0 & 45 & 0 \\
\hline \multirow[t]{4}{*}{ Richter 110 (4) } & I & 35 & 0 & 5 & 0 \\
\hline & II & 2,065 & 0 & 295 & 0.7 \\
\hline & III & 2,590 & 0.1 & 370 & 0 \\
\hline & IV & 770 & 0 & 110 & 0 \\
\hline \multirow[t]{4}{*}{ Seyval Blanc (5) } & I & 245 & 0 & 35 & 0 \\
\hline & II & 245 & 3.3 & 35 & 0 \\
\hline & III & 1,085 & 0.3 & 155 & 1.9 \\
\hline & IV & 1,435 & 0 & 205 & 2.0 \\
\hline \multirow[t]{4}{*}{ Stover (5) } & I & 1,505 & 0.1 & 215 & 0.5 \\
\hline & II & 5,355 & 0.4 & 765 & 2.6 \\
\hline & III & 5,495 & 0.2 & 785 & 1.7 \\
\hline & IV & 1,925 & 0.4 & 275 & 2.2 \\
\hline \multirow[t]{4}{*}{ Tampa (3) } & I & 280 & 0 & 40 & 0 \\
\hline & II & 840 & 0 & 120 & 0.8 \\
\hline & III & 350 & 0 & 50 & 0.8 \\
\hline & IV & 280 & 1.8 & 40 & 0 \\
\hline & & & 0.2 & & 0.3 \\
\hline \multicolumn{3}{|l|}{ Heterogenity $\chi^{2}$ results } & $\mathrm{df}$ & $\chi^{2}$ & $P$ value \\
\hline \multicolumn{3}{|c|}{ Variety $\times$ stage $($ percent responsive stamens) } & 75 & 40.84 & 0.522 \\
\hline \multicolumn{3}{|c|}{ Variety $\times$ stage (percent embryogenic pistils) } & 75 & 133.31 & $<0.001$ \\
\hline
\end{tabular}

Data were analyzed using heterogeneity $\chi 2$ test for independence. SE values for percent embryogenic stamen and pistil explants are included at the end of the table. Data represents the cumulative response of explants on 8 culture media.

${ }^{z}$ Numbers in parenthesis indicate the number of years cultures were initiated to study embryogenic response from anther and stamen explants.

$30 \mathrm{~s}$. Inflorescences were then washed in $25 \%$ $\mathrm{NaClO}$ solution containing one drop Triton X100 with constant agitation for $5 \mathrm{~min}$ followed by three 5-min washes in sterile distilled water. Stamens (anthers with intact filaments) were carefully separated from the calyptra and the pistil before placing them on the medium. The pistil with the remaining filament stubs also was recovered and placed on the medium. Each petri dish contained 35 stamens in a clump in the center along with the pistils from which they were obtained placed near the perimeter. Petri dishes were sealed with Parafilm ${ }^{\circledR}$ (Fisher Scientific International, Inc., Hampton, NH) and placed in darkness at $26{ }^{\circ} \mathrm{C}$. Four floral stages were recognized based on the size of inflorescences and individual flowers, anther size, and anther color (Fig. 2):

Stage I. Flower clusters were $\approx 2.5$ to $3.0 \mathrm{~cm}$ long, individual flower buds 0.5 to $0.7 \mathrm{~mm}$ in diameter, and anthers 0.1 to 0.2 $\mathrm{mm}$ in length, white in color and clear in appearance (Fig. 2A-B). Anthers were fragile and extremely difficult to observe at this stage. Microspores were single-celled and densely cytoplasmic with thin cell walls when mounted in 4\% mannitol.

Stage II. Flower clusters were $\approx 6$ to $8 \mathrm{~cm}$ long and individual flower buds $\approx 1.5 \mathrm{~mm}$ in diameter. Anthers were 0.8 to $1.0 \mathrm{~mm}$ long, yellowish in color, and appeared translucent with clear walls (Fig. 2C-D). The locule was cloudy and white in color. Microspores were yellowish in color and densely cytoplasmic with a thickening wall.

Stage III. Flower clusters were $\approx 9$ to $10 \mathrm{~cm}$ long and individual flower buds were 1.5 to $2.0 \mathrm{~mm}$ in diameter. Anthers were $1.0 \mathrm{~mm}$ in length, yellowish in color, and cloudy in appearance with clear walls (Fig. 2E-F). The locule was cloudy and yellowish in color. Microspore walls were thicker and well developed.

Stage IV. Flower clusters greater than $10 \mathrm{~cm}$ in length and individual flower diameter was similar to Stage III. Anthers were $1.0 \mathrm{~mm}$ long and yellowish in color (Fig. $2 \mathrm{G}-$ $\mathrm{H})$ with completely opaque walls. The locule was yellow in color and opaque. Microspore walls were thicker and pores in the cell wall were evident. The number of stamens and pistils cultured from each developmental stage varied according to the availability of flower buds at the particular stage.

After 4 weeks, cultures were transferred to cool-white fluorescent lights $\left(65 \mu \mathrm{mole} \cdot \mathrm{m}^{-2} \cdot \mathrm{s}^{-1}\right.$ and a 16-h photoperiod). Developing cultures were examined using a microscope for the presence of embryogenic callus at weekly intervals for 16 weeks.

\section{Influence of culture medium on embryogenic competence}

The influence of eight medium formulations on embryogenic competence was examined (Table 1). Embryogenic response of leaves was tested on NB2 medium while the embryogenic response of stamens and pistils was compared on the remaining media. Most media were supplemented with $2 \%$ sucrose and $\mathrm{pH}$-adjusted with $1 \mathrm{~N} \mathrm{KOH}$ before the addition of $7 \mathrm{~g} \cdot \mathrm{L}^{-1}$ TC agar (Phytotechnology Laboratories, LLC, Shawnee Mission, KS; Catalog No. A 175) with the exception of PIV medium (Franks et al., 1998), which was supplemented with $6 \%$ sucrose and $3 \mathrm{~g} \cdot \mathrm{L}^{-1}$ Phytage $^{\circledR}$ (Sigma-Aldrich Co., St. Louis, MO). All media were autoclaved at $120^{\circ} \mathrm{C}$ and $1.1 \mathrm{~kg} \cdot \mathrm{cm}^{-2}$ for $20 \mathrm{~min}$ and $25 \mathrm{~mL}$ medium was dispensed into each $100 \times 15-\mathrm{mm}$ petri dish

\section{Maintenance of embryogenic cultures}

The development of embryogenic callus from a stamen or pistil was recorded as a positive response with calluses being transferred to X6 medium for PEM and SE development. PEM and SE were transferred 
to fresh X6 medium at 4- to 6-week intervals as previously described (Li et al., 2008). After the first transfer, $0.2 \mathrm{~g}$ of PEM from each variety was transferred to fresh X6 medium. The number of cotyledonary-stage SE was recorded after 6 weeks to evaluate differences in embryogenic competence. There were three petri dishes for each variety, each comprising a replication. The experiment was conducted three times.

\section{Somatic embryo germination and plant regeneration}

Cotyledonary stage SE from Vitis genotypes were induced to germinate on MS1B medium (Dhekney et al., 2008). Five SE were placed in each petri dish, which was replicated three times. Enlarged cotyledons were excised after 2 weeks to permit faster shoot growth and development ( $\mathrm{Li}$ et al., 2008). The number of plants developing from each variety was recorded. Plants with a robust shoot and root system were subsequently transferred to Magenta M-7 boxes (Fisher Scientific International, Inc., Hampton, NH) containing $30 \mathrm{~mL}$ MS medium for further development. Well-developed plants were acclimatized by placing them in transparent plastic domes under cool-white fluorescent lights $\left(65 \mu \mathrm{mole} \cdot \mathrm{m}^{-2} \cdot \mathrm{s}^{-1}\right.$ and a $16-\mathrm{h}$ photoperiod) at $26{ }^{\circ} \mathrm{C}$ for 3 weeks and then transferred to a greenhouse.

\section{Statistical analysis}

Categorical, count, and percentage data were analyzed using heterogeneity $\chi^{2}$ testing for independence (Compton, 2005; Zarr, 1984). Treatment means of variables with a significant $\chi^{2}(\alpha \leq 0.05)$ were compared using the sample SE (Mize et al., 1999). Data for plant recovery from germinated SE were analyzed using Proc GLM and analysis of variance procedures of Statistical Analysis Systems (2001).

\section{Results and Discussion}

Influence of genotype and explant type. Leaf explants cultured on NB2 medium produced sectors of compact, cream-colored embryogenic callus and loose, browncolored nonembryogenic callus (Fig. 1B). Of 15 varieties tested, only six produced embryogenic callus (Fig. 3). The highest percentage of embryogenic competent explants was recorded in 'Superior Seedless' (72\%) and 'Thompson Seedless' (53\%). Transfer of embryogenic callus to growth regulator-free X6 medium resulted in the production of somatic embryos. Leaves from all three seedless varieties evaluated produced embryogenic cultures. At this point, however, it is unknown if seedlessness could be a potential factor influencing embryogenesis from leaf explants because seeded $V$. rupestris 'St. George' and complex interspecific hybrids 'Freedom' and 'Seyval Blanc' also responded. More seedless varieties should be evaluated before a definitive relationship can be established.

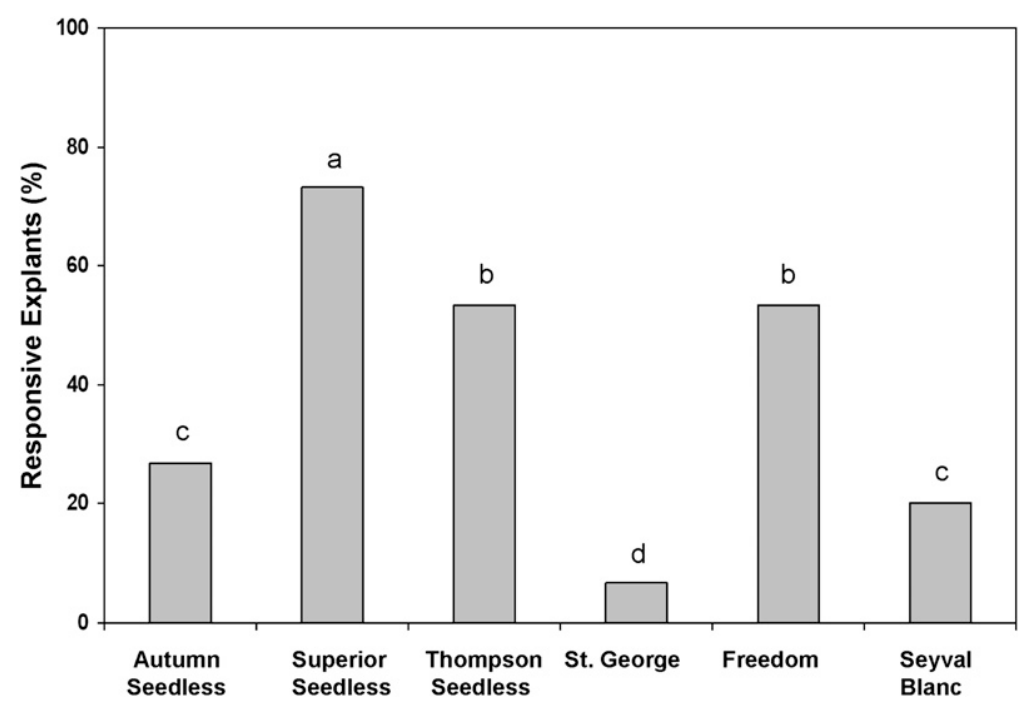

Fig. 3. Embryogenic response of Vitis leaf explants on NB2 medium. Five explants were placed in each Petridish containing $25 \mathrm{~mL} \mathrm{NB} 2$ medium with three replicates. Embryogenic response was recorded after 10 to 12 weeks. Means with the same letter are not statistically significant according to standard error of means $(\mathrm{SEM}=8.1)$.

Table 3. Embryogenic response of Vitis varieties on seven media treatments.

\begin{tabular}{|c|c|c|c|c|c|}
\hline Variety & Medium $^{z}$ & $\begin{array}{c}\text { No. of } \\
\text { stamens } \\
\text { cultured }\end{array}$ & $\begin{array}{c}\text { Percent } \\
\text { embryogenic } \\
\text { stamens }\end{array}$ & $\begin{array}{l}\text { No. of } \\
\text { pistils } \\
\text { cultured }\end{array}$ & $\begin{array}{c}\text { Percent } \\
\text { embryogenic } \\
\text { pistils }\end{array}$ \\
\hline & & Vitis vinifera & & & \\
\hline \multirow[t]{2}{*}{ Barbera $(3)^{\mathrm{y}}$} & $\mathrm{X} 1$ & 1,155 & 0.09 & 165 & 1.2 \\
\hline & $\mathrm{X} 2$ & 1,330 & 0 & 190 & 1.1 \\
\hline \multirow[t]{4}{*}{ Cabernet Franc (7) } & MSI & 5,110 & 2.4 & 730 & 7.3 \\
\hline & PIV & 1,400 & 0.6 & 200 & 6.0 \\
\hline & $\mathrm{X} 1$ & 3,325 & 0.3 & 475 & 2.3 \\
\hline & $\mathrm{X} 2$ & 3,115 & 2.1 & 445 & 4.5 \\
\hline \multirow[t]{5}{*}{ Cabernet Sauvignon (10) } & MSI & 10,080 & 0.1 & 1,440 & 1.6 \\
\hline & MSII & 5,005 & 0.06 & 715 & 1.7 \\
\hline & PIV & 4,060 & 0.2 & 580 & 1.9 \\
\hline & $\mathrm{X} 1$ & 9,205 & 0.05 & 1,315 & 0.3 \\
\hline & $\mathrm{X} 2$ & 8,960 & 0.5 & 1,280 & 0.08 \\
\hline \multirow[t]{7}{*}{ Chardonnay (8) } & MSI & 1,680 & 1.3 & 240 & 3.3 \\
\hline & MSII & 1,680 & 2.8 & 240 & 6.3 \\
\hline & NI & 770 & 0.5 & 110 & 6.4 \\
\hline & NII & 735 & 0.4 & 105 & 1.0 \\
\hline & PIV & 980 & 1.8 & 145 & 3.4 \\
\hline & $\mathrm{X} 1$ & 910 & 4.4 & 130 & 4.6 \\
\hline & $\mathrm{X} 2$ & 1,260 & 1.1 & 180 & 2.8 \\
\hline Dolcetto (3) & $\mathrm{X} 1$ & 3,955 & 0.03 & 565 & 0 \\
\hline Emerald Seedless (3) & MSI & 3,570 & 4.3 & 510 & 0.4 \\
\hline \multirow[t]{7}{*}{ Merlot (9) } & MSI & 3,995 & 10.8 & 265 & 35.1 \\
\hline & MSII & 2,065 & 7.9 & 295 & 7.8 \\
\hline & NI & 350 & 8.1 & 50 & 6 \\
\hline & NII & 385 & 4.7 & 55 & 0 \\
\hline & PIV & 1,575 & 17.6 & 225 & 24 \\
\hline & $\mathrm{X} 1$ & 665 & 9.6 & 95 & 4.2 \\
\hline & $\mathrm{X} 2$ & 700 & 3.4 & 100 & 2.0 \\
\hline \multirow[t]{3}{*}{ Orange Muscat (4) } & MSI & 2,450 & 4.4 & 350 & 12.9 \\
\hline & MSII & 840 & 5.5 & 120 & 13.3 \\
\hline & PIV & 910 & 2.4 & 130 & 17.7 \\
\hline \multirow[t]{2}{*}{ Pinotage (3) } & MSI & 4,725 & 0.02 & 675 & 0.3 \\
\hline & PIV & 1,785 & 0 & 255 & 0.4 \\
\hline Pinot Gris (3) & MSI & 3,080 & 0.03 & 440 & 0.2 \\
\hline \multirow[t]{3}{*}{ Pinot Noir (6) } & MSI & 2,485 & 2.8 & 355 & 1.1 \\
\hline & MSII & 2,730 & 3.5 & 390 & 0.8 \\
\hline & PIV & 805 & 0.2 & 115 & 0.9 \\
\hline \multirow[t]{6}{*}{ Sauvignon Blanc (5) } & MSI & 1,260 & 0.08 & 180 & 2.8 \\
\hline & MSII & 1,435 & 0.7 & 205 & 4.4 \\
\hline & NI & 245 & 0 & 35 & 5.7 \\
\hline & NII & 245 & 0 & 35 & 5.7 \\
\hline & PIV & 1,505 & 0 & 215 & 4.2 \\
\hline & $\mathrm{X} 1$ & 315 & 0.3 & 45 & 4.4 \\
\hline
\end{tabular}

(Continued on next page) 
Table 3. (Continued) Embryogenic response of Vitis varieties on seven media treatments.

\begin{tabular}{|c|c|c|c|c|c|}
\hline Variety & Medium $^{z}$ & $\begin{array}{c}\text { No. of } \\
\text { stamens } \\
\text { cultured }\end{array}$ & $\begin{array}{c}\text { Percent } \\
\text { embryogenic } \\
\text { stamens }\end{array}$ & $\begin{array}{l}\text { No. of } \\
\text { pistils } \\
\text { cultured }\end{array}$ & $\begin{array}{c}\text { Percent } \\
\text { embryogenic } \\
\text { pistils }\end{array}$ \\
\hline Shiraz (5) & MSI & 4,165 & 0.6 & 595 & 0.2 \\
\hline \multirow[t]{4}{*}{ Thompson Seedless (7) } & MSI & 1,610 & 9.8 & 230 & 3.9 \\
\hline & MSII & 1,435 & 11.6 & 205 & 3.4 \\
\hline & NI & 875 & 4.8 & 125 & 0.8 \\
\hline & PIV & 280 & 27.1 & 40 & 10 \\
\hline \multirow[t]{7}{*}{ White Riesling (10) } & MSI & 6,055 & 5.5 & 865 & 5.1 \\
\hline & MSII & 2,100 & 5.9 & 300 & 8.3 \\
\hline & NI & 1,365 & 2.2 & 195 & 2.6 \\
\hline & NII & 1,260 & 0.2 & 180 & 0.6 \\
\hline & PIV & 1,155 & 5.5 & 165 & 4.8 \\
\hline & $\mathrm{X} 1$ & 7,770 & 3.8 & 1,110 & 7.6 \\
\hline & $\mathrm{X} 2$ & 4,095 & 1.4 & 585 & 3.9 \\
\hline Zinfandel (6) & $\mathrm{X} 1$ & 3,010 & 0.2 & 430 & 0.5 \\
\hline V. champinii (3) & MSI & 1,750 & 0.80 & 250 & 0 \\
\hline \multirow[t]{3}{*}{ V. riparia Gloire (3) } & MSI & 4,550 & 0.5 & 650 & 1.7 \\
\hline & PIV & 805 & 0.1 & 115 & 5.2 \\
\hline & $\mathrm{X} 2$ & 2,975 & 0.2 & 425 & 2.6 \\
\hline \multirow[t]{3}{*}{ V. rupestris St.George (3) } & $\mathrm{X} 1$ & 1,190 & 0.8 & 170 & 0 \\
\hline & $\mathrm{X} 2$ & 1,365 & 0.4 & 195 & 0.5 \\
\hline & NI & 700 & 0.42 & 100 & 0 \\
\hline \multicolumn{6}{|c|}{ Vitis hybrids } \\
\hline \multirow[t]{4}{*}{ Blanc du Bois (7) } & $\mathrm{X} 1$ & 5,040 & 0.2 & 720 & 0 \\
\hline & $\mathrm{X} 2$ & 4,585 & 0.1 & 655 & 0 \\
\hline & N I & 1,115 & 0.1 & 165 & 0 \\
\hline & N II & 1,225 & 0.2 & 175 & 0 \\
\hline \multirow[t]{4}{*}{ Conquistador (5) } & MSI & 1,295 & 0.69 & 161 & 0 \\
\hline & NI & 105 & 1 & 15 & 0 \\
\hline & NII & 70 & 1.4 & 10 & 0 \\
\hline & PIV & 175 & 0 & 25 & 4.0 \\
\hline \multirow[t]{2}{*}{ Freedom (5) } & MSI & 770 & 0 & 110 & 5.5 \\
\hline & MSII & 805 & 0 & 115 & 0.9 \\
\hline Harmony (3) & MSI & 2,030 & 0.54 & 290 & 0 \\
\hline \multirow[t]{2}{*}{ Richter 110 (4) } & MSI & 4,585 & 0.02 & 655 & 0.3 \\
\hline & PIV & 875 & 0.1 & 125 & 0 \\
\hline \multirow[t]{6}{*}{ Seyval Blanc (5) } & MSI & 525 & 0 & 75 & 1.3 \\
\hline & MSII & 350 & 0 & 50 & 4.0 \\
\hline & NI & 245 & 0 & 35 & 2. \\
\hline & NII & 175 & 0.6 & 25 & 0 \\
\hline & PIV & 490 & 2.0 & 70 & 0 \\
\hline & $\mathrm{X} 1$ & 210 & 0 & 30 & 10.0 \\
\hline \multirow[t]{5}{*}{ Stover (5) } & $\mathrm{X} 1$ & 4,655 & 0 & 665 & 0.3 \\
\hline & $\mathrm{X} 2$ & 4,725 & 0.02 & 675 & 0.4 \\
\hline & NI & 1,365 & 0.5 & 195 & 1.0 \\
\hline & NII & 1,365 & 2.19 & 195 & 16.4 \\
\hline & PIV & 805 & 0.1 & 115 & 5.2 \\
\hline \multirow[t]{2}{*}{ Tampa (3) } & MSII & 280 & 0 & 40 & 2.5 \\
\hline & PIV & 595 & 0.8 & 85 & 1.2 \\
\hline SE & & & 0.5 & & 0.6 \\
\hline \multicolumn{3}{|l|}{ Heterogenity $\chi^{2}$ results } & DF & $\chi^{2}$ & $P$ value \\
\hline \multicolumn{3}{|c|}{ Variety $\times$ medium (percent responsive stamens) } & 60 & 163.26 & $<0.001$ \\
\hline \multicolumn{3}{|c|}{ Variety $\times$ medium (percent embryogenic pistils) } & 60 & 423.18 & $<0.001$ \\
\hline
\end{tabular}

${ }^{2}$ Data for only those medium treatments that produced an embryogenic response from either stamen or pistil explants has been provided. Data were analyzed using heterogeneity $\chi^{2}$ test for independence. SE values for percent embryogenic stamen and pistil explants are included at the end of the table. Data represents the cumulative response of four developmental stages of explants.

${ }^{y}$ Numbers in parentheses indicate the number of years cultures were initiated to study embryogenic response from anther and stamen explants.

Embryogenic response from stamens and pistils at four developmental stages was studied. Several reports of grapevine embryogenesis describe explants as anthers and ovaries (Carmi et al., 2005; Perrin et al., 2001, 2004). We consider this to be an incorrect designation of explants, because entire stamens and pistils are excised from developing inflorescences and cultured. The embryogenic response of stamens and pistils was variety-dependent. Among 26 varieties tested, a greater number produced embryogenic cultures from stamens (25) com- pared with pistils (22) after 16 to 18 weeks (Table 2). These results contrast earlier studies (Kikkert et al., 2005) in which ovaries were found to be more responsive. Callus production from stamen explants occurred almost exclusively from the filament tip or the connective tissue (Fig. 1D-E). In most cases, the anthers failed to callus, turning brown during the culture period (Fig. 1E). Somatic embryos and subsequent plant regeneration most probably occurred from somatic tissues rather than microspores in as much as earlier studies using cytological and genetic evidence (Bouquet et al., 1982; Rajasekaran and Mullins, 1983) demonstrated a somatic origin of calli and subsequent plant regeneration. Because embryogenic cultures arose exclusively from somatic tissues including the filament and anther wall, it was unnecessary to stain anthers and determine the developmental stage of microspores as suggested in previous studies (Hollo and Misik, 2000; Krastanova et al., 2000). The culture of intact stamens (anthers with attached filament) was essential for obtaining an embryogenic response. No response was observed from stamen explants with damaged filaments or when anthers were detached from filaments and cultured separately (data not shown). Similarly, detached filament explants failed to respond (data not shown). These results contrast studies (Perrin et al., 2004) in which wounding of anthers led to a greater embryogenic response. Although embryogenic cultures were obtained from all four developmental stages of explants in some varieties, more varieties as well as a greater percentage of explants produced cultures at Stage II and III of development. Compared with the number of varieties producing embryogenic cultures from Stage I (13) and IV (15) explants, more varieties were responsive from Stage II (18) and Stage III (21) explants. Although no significant differences were observed among stamen explants $(P=0.522)$, pistil explants at different stages of development differed significantly in their embryogenic response $(P<0.001)$. Among the four explant stages cultured, the highest embryogenic response among varieties was observed when Stage II and III explants were used (Table 2). Similarly, the percentage of explants responding from Stage II and Stage III were greater compared with the other stages. Earlier reports of grape somatic embryogenesis from anthers suggested a higher embryogenic response when translucent green-yellow anthers were cultured (Goussard et al., 1991; Newton and Goussard, 1990); however, a detailed description of developmental stages was not provided. Because grapevine flowering occurs only once a year in most regions and provides a short timeframe for culture initiation, a complete description of explant stages along with photographic evidence (Fig. 2) should serve as a comprehensive guideline for successful culture initiation. Among the varieties evaluated, the highest embryogenic response was observed from 'Merlot' stamens and pistils $(11.6 \% \pm$ $0.2 \%$ and $13.8 \% \pm 0.3 \%$ ) followed by 'Thompson Seedless' $(10.5 \% \pm 0.2 \%$ and $8.3 \% \pm 0.3 \%)$ and 'White Riesling' (3.7\% \pm $0.2 \%$ and $5.9 \% \pm 0.3 \%$ ), respectively.

Embryogenic culture initiation on seven medium treatments. A significant difference in embryogenic response was obtained from both stamens and pistils $(P<0.001)$ on seven medium treatments (Table 3). Embryogenic cultures from stamens were established from the maximum number of varieties on MSI medium (18) followed by PIV (16), X1 (11), and MSII (11). A similar response was observed from pistils cultured on these media. 
Among the varieties studied, the highest percentage of stamens producing embryogenic callus was recorded in 'Thompson Seedless' on PIV medium $(27.1 \% \pm 0.5 \%)$, whereas 'Merlot' pistils produced the greatest response $(35.1 \% \pm 0.6 \%)$ on MSI medium. Embryogenic cultures were obtained from explants of all 26 varieties tested. MSI medium comprises of MS macro- and microelements (Murashige and Skoog, 1962) and has a higher macroelement concentration compared with PIV medium (Franks et al., 1998), which is comprised of Nitsch macroand microelements (Nitsch and Nitsch, 1969). PIV medium, however, has higher levels of growth regulators $(8.9 \mu \mathrm{M}$ BAP and $4.5 \mu \mathrm{M}$ 2,4-D) compared with MSI medium $(4.5 \mu \mathrm{M} 2,4-\mathrm{D}$ and $5.0 \mu \mathrm{M}$ BAP). Other varieties responded solely on X1 medium, which is characterized by significantly higher inorganic nitrogen levels compared with MSI and PIV media. Thus, embryogenic competence appears to result from a complex interaction of several factors, including variety, macro- and micronutrient levels, and growth regulator concentration. Earlier studies involving grape embryogenesis used various media and growth regulator combinations to produce embryogenic cultures (Iocco et al., 2001; Kikkert et al., 2005; Perrin et al., 2004); however, the basal salts used in these media also were either MS or Nitsch.

Maintenance of embryogenic cultures. Embryogenic callus obtained from leaf, stamen, and pistil explants produced somatic embryos after transfer to X6 medium. Cultures growing on X6 medium typically were comprised of PEM along with SE at the globular, heart, torpedo, and cotyledonary stages of development (Fig. 1F). Embryogenic cultures were maintained by careful transfer of proliferating PEM to fresh X6 medium at 4- to 6-week intervals. To evaluate differences in embryogenic competence among varieties, the number of cotyledonary stage SE produced from $0.2 \mathrm{~g}$ PEM was recorded after 6 weeks on X6 medium. Production of SE (embryogenic competence) on X6 medium was variety-dependent (Fig. 4). The maximum number of SE was produced from 'Thompson Seedless' (927) followed by 'Merlot' (575) and 'Shiraz' (569). X6 medium is characterized by higher levels of inorganic nitrogen, $\mathrm{NH}_{4} \mathrm{Cl}$ as a source of $\mathrm{NH}_{4}$ ion, and the presence of activated charcoal (Dhekney et al., 2008; Li et al., 2008). Grapevine SE proliferate by direct secondary embryogenesis with new embryos emerging from epidermal or subepidermal cells (Gray, 1995; Jayasankar et al., 2003). Thus, cultures could be maintained for a long period of time on this medium by careful transfer of PEM to fresh medium at 4- to 6-week intervals (Gray, 1995). In contrast to previous reports (Kikkert et al., 2005; Perrin et al., 2004), X6 medium was optimum for maintenance of embryogenic cultures of all varieties regardless of the medium from which they were initiated. Use of a single medium greatly increases the ease of long-term culture main-

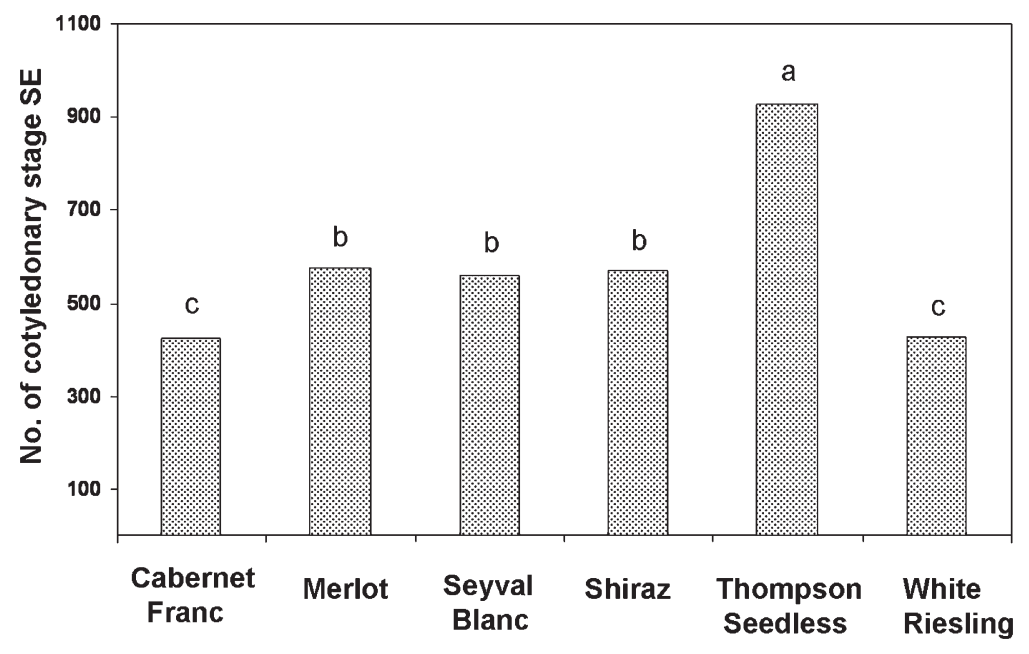

Fig. 4. Embryogenic competence of Vitis varieties. The number of cotyledonary stage somatic embryo obtained from $0.2 \mathrm{~g}$ proliferating proembryonic masses after 6 weeks of culture on X6 medium was recorded as the embryogenic potential of a variety. Means with the same letter are not statistically significant according to standard error of means $(\mathrm{SEM}=44)$.

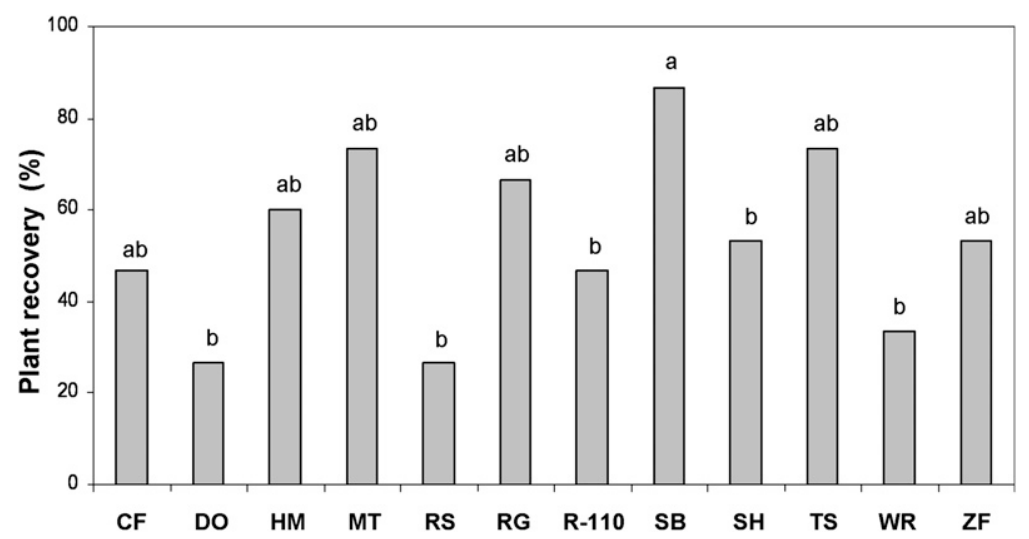

Fig. 5. Plant recovery from germinated somatic embryo (SE) of Vitis varieties 'Cabernet Franc' (CF), 'Dolcetto' (DO), 'Harmony' (HM), 'Merlot' (MT), 'Ramsey' (RS), 'Riparia Gloire' (RS), 'Richter 110' (R-110), 'Seyval Blanc' (SB), 'Shiraz' (SH), 'Thompson Seedless' (TS), 'White Riesling' (WR), and 'Zinfandel' (ZF). Five cotyledonary stage SE were placed in a petri dish containing $25 \mathrm{~mL}$ MS1B medium with three replicates. Statistical analysis was carried using Proc GLM and analysis of variance procedures of SAS. Bars represented by the same letter are not significantly different according to Student-Newman-Keuls test $(\alpha=0.05)$.

tenance after initiation. An important factor affecting maintenance of embryogenic cultures was the use of TC agar as a gelling agent. Use of other gelling agents, including Bactoagar and Phytagel, in X6 medium resulted in a rapid decline in embryogenic competence and eventual termination of cultures (unpublished results). Use of TC agar or an equivalent type is therefore a critical factor for ensuring successful long-term maintenance of embryogenic cultures.

Somatic embryo germination and plant regeneration. SE germinated after transfer to MS1B medium (Fig. 1G). Plant recovery from germinated SE was variety-dependent (Fig. 5). Among the 11 varieties evaluated, the maximum plant recovery from germinated SE was observed for 'Seyval Blanc' (86.7\%) followed by 'Thompson Seedless' and 'Merlot' $(73.3 \%$ each). Plants with a shoot and root system were transferred to
Magenta M-7 boxes (Fig. 1H) and successfully established in a greenhouse after acclimatization. Several treatments have been used to improve grapevine SE germination (Gray, 1989; Jayasankar et al., 2005); however, cotyledon excision of germinated SE is a simple method resulting in greater plant recovery (Li et al., 2008).

Embryogenic cultures now are used routinely in Vitis for production of transgenic plants with desirable traits (Dhekney et al., 2008, 2009; Li et al., 2001, 2006, 2008). The protocols described here can assist in rapid initiation and establishment of cultures for use in genetic transformation studies.

\section{Literature Cited}

Bouquet, A., B. Piganeau, and A.M. Lamaison. 1982. Influence du genotype sur la production de calm d'embryoides et de plantes eniteres par 
culture d'antheres in vitro dans le genre Vitis C.R. Acad Sci. 295:569-574.

Carmi, F., E. Barriza, M. Gardiman, and F. Schiavo. 2005. Somatic embryogenesis from stigmas and styles of grapevine. In Vitro Cell. Dev. Biol. Plant 41:249-252.

Compton, M.E. 2005. Elements of in vitro research, p. 55-71. In: Trigiano, R.N. and D.J. Gray (eds.). Plant development and biotechnology, CRC Press, Boca Raton, FL.

Dhekney, S.A., Z.T. Li, M. Dutt, and D.J. Gray. 2008. Agrobacterium-mediated transformation of embryogenic cultures and regeneration of transgenic plants in Vitis routundifolia Michx. (muscadine grape). Plant Cell Rpt. 27:865-872.

Dhekney, S.A., Z.T. Li, T.W. Zimmerman, and D.J. Gray. 2009. Factors influencing genetic transformation and plant regeneration of Vitis. Amer. J. Enol. Viticult. 60:285-292.

Franks, T., D.G. He, and M. Thomas. 1998. Regeneration of transgenic Vitis vinifera L. Sultana plants: Genotypic and phenotypic analysis. Mol. Breed. 4:321-333.

Goussard, P.G., J. Wild, and G.G.F. Kasdor. 1991. The effectiveness of in vitro somatic embryogenesis in eliminating fanleaf virus and leafroll associated viruses from grapevines. S. Afric. J. Enol. Vitic. 12:77-83.

Gray, D.J. 1989. Effect of dehydration and exogenous growth regulators on dormancy, quiescence and germination of grape somatic embryos. In Vitro Cell. Dev. Biol. Plant 25: 1173-1178.

Gray, D.J. 1995. Somatic embryogenesis in grape, p. 191-217. In: Jain, S.M., P.K. Gupta, and R.J. Newton (eds.). Somatic embryogenesis in woody plants. 2. Kluwer Academic Publishers, Dordrecht, The Netherlands.

Gray, D.J. and C.M. Benton. 1991. In vitro micropropagation and plant establishment of muscadine grape cultivars (Vitis rotundifolia). Plant Cell Tissue Organ Cult. 27:7-14.
Gray, D.J., S. Jayasankar, and Z. Li. 2005. Vitis spp. grape, p. 672-706. In: Litz, R.E. (ed.). Biotechnology of fruit and nut crops, $\mathrm{CAB}$ International Wallingford, Oxford, UK.

Gray, D.J. and J.A. Mortensen. 1987. Initiation and maintenance of long term somatic embryogenesis from anthers and ovaries of Vitis longii 'Microsperma'. Plant Cell Tissue Organ Cult. 9:73-80.

Hollo, R. and S. Misik. 2000. Investigation of grape anther culture aiming haploid plant production. Acta Hort. 528:347-350.

Iocco, P., T. Franks, and M.R. Thomas. 2001. Genetic transformation of major wine grape varieties of Vitis vinifera L. Transgenic Res. 10:105-112.

Jayasankar, S., B.R. Bondada, Z. Li, and D.J. Gray. 2003. Comparative anatomy and morphology of Vitis vinifera (Vitaceae) somatic embryos from solid and liquid culture systems. Amer. J. Bot. 90:973-979.

Jayasankar, S., M. Van Aman, J. Cordts, Z. Li, S. Dhekney, and D.J. Gray. 2005. Long term storage of suspension culture-derived grapevine somatic embryos and regeneration of plants. In Vitro Cell. Dev. Biol. Plant 41:752756.

Kikkert, J., M.J. Striem, J.R. Vidal, P.G. Wallace, J. Barnard, and B. Reisch. 2005. Long term study of somatic embryogenesis from anthers and ovaries of 12 grapevine (Vitis) genotypes. In Vitro Cell. Dev. Biol. Plant 41:232-239.

Krastanova, S., K.S. Ling, H.Y. Zhu, B. Xue, T.J. Burr, and D. Gonsalves. 2000. Development of transgenic grapevine rootstocks with genes from grape fan leaf virus and grapevine leafroll associated clostereoviruses 2 and 3. Acta Hort. 528:367-372.

Li, Z., S. Jayasankar, and D.J. Gray. 2001. Expression of a bifunctional green fluorescent protein (GFP) fusion marker under the control of three constitutive promoters and enhanced deriva- tives in transgenic grape (Vitis vinifera). Plant Sci. 160:877-887.

Li, Z.T., S.A. Dhekney, M. Dutt, and D.J. Gray. 2008. An improved protocol for Agrobacterium-mediated transformation of grapevine. Plant Cell Tissue Organ Cult. 93:311-321.

Li, Z.T., S.A. Dhekney, M. Dutt, M. Van Aman, J. Tattersall, K.T. Kelley, and D.J. Gray. 2006. Optimizing Agrobacterium-mediated transformation of grapevine. In Vitro Cell. Dev. Biol. Plant 42:220-227.

Mize, C.W., K.J. Koehler, and M.E. Compton. 1999. Statistical considerations for in vitro research: II-Data to presentation. In Vitro Cell. Dev. Biol. Plant 35:122-126.

Murashige, T. and F. Skoog. 1962. A revised medium for rapid growth and bioassays with tobacco tissue cultures. Physiol. Plant. 15:473497.

Newton, D.J. and P.G. Goussard. 1990. The ontogeny of somatic embryos from in vitro cultured grapevine anthers. S. Afric. J. Enol. Vitic. 11:70-81.

Nitsch, J.P. and C. Nitsch. 1969. Haploid plants from pollen grains. Science 163:85-87.

Perrin, M., C. Gertz, and J.E. Masson. 2004. High efficiency initiation of regenerable embryogenic callus from anther filaments of 19 grapevine genotypes grown worldwide. Plant Sci. 167:1343-1349.

Perrin, M., D. Martin, D. Joly, G. Demangeat, P. This, and J.E. Masson. 2001. Medium dependent response of grapevine somatic embryogenic cells. Plant Sci. 161:107-116.

Rajasekaran, K. and M.G. Mullins. 1983. Influence of genotype and sex expression on formation of plantlets by cultured anthers of grapevines. Agronomie 3:233-238.

Statistical Analysis Systems. 2001. SAS Institute, Cary, NC.

Zarr, J.H. 1984. Biostatistical analysis. 2nd Ed. Prentice Hall, Englewood Cliffs, NJ. 